\title{
Inflammatory cells in the lungs of premature infants on the first day of life: perinatal risk factors and origin of cells
}

\author{
Jonathan Grigg, Shmuel Arnon, Andrew Chase, Michael Silverman
}

\begin{abstract}
Neither the origin of leucocytes in the premature newborn airway nor their relationship to perinatal factors has been adequately determined. In order to sample airway cells, modified bronchoalveolar lavage was performed on 74 intubated infants of $<32$ weeks' gestation and $<24$ hours of age. Cells were counted, stained and, in a small separate group of six infants, four boys and two girls, probed for the $Y$ chromosome with suitable control samples. Perinatal risk factors for increased airway cellularity were analysed by multiple regression. Premature rupture of membranes of more than 24 hours' duration was independently associated with increased numbers of airway leucocytes $(n=74)$. More than $90 \%$ of airway leucocytes from four boys with pulmonary inflammation were positive for the $Y$ chromosome indicating that the cells were of fetal rather than maternal origin.
\end{abstract}

(Arch Dis Child 1993; 69: 40-43)

The number of neutrophil leucocytes in the airway of newborn premature infants can be significantly affected by perinatal factors. For example, in a small group of newborn premature infants we have observed increased numbers of leucocytes in bronchoalveolar lavage fluid (BALF) after premature rupture of membranes (PROM) for more than 24 hours. $^{1}$ The clinical significance of this finding is unknown but Fujimura et al have described an increased incidence of placental inflammation in a group of premature infants without respiratory distress syndrome but who subsequently developed chronic lung disease. ${ }^{2}$ It is therefore possible that perinatal intrauterine inflammation may, in some way, induce damage in the lung of the fetus and neonate.

The relative importance of various perinatal factors for pulmonary inflammation in the fetus and newborn infant has never been demonstrated. In addition, the relationship between pulmonary inflammation in the fetus and inflammation in the amniotic fluid is unknown. Inflammatory cells in the fetal airway could arise from either inhalation of cells from the amniotic fluid or from an intrinsic response. Inhalation of amniotic fluid cells could be proved if most of the airway leucocytes in boys at birth were of maternal origin, as it has been shown that amniotic fluid leuco- cytes are mainly maternal in origin. $^{3}$ Alternatively, the fetal origin of inflammatory cells would be convincingly demonstrated if, in boys, airway cells were of male origin.

In this study, we sought to characterise some of the perinatal risk factors independently associated with pulmonary inflammation in the newborn premature infant. In addition, we aimed to determine whether airway neutrophils at birth were of maternal or fetal origin. In achieving these aims, we used 'blindly' wedged bronchoalveolar lavage and probed cells for the $\mathrm{Y}$ chromosome using in situ hybridisation.

\section{Subjects and methods \\ SUBJECTS}

Seventy four infants intubated for respiratory disease were studied. All were $<32$ weeks' gestation (mean 27.3 weeks) and underwent bronchoalveolar lavage between 4 and 24 hours of age. Antibiotics had been given before lavage but no infant had received surfactant. Almost all of the febrile mothers had been given antibiotics before delivery. Clinical data recorded at the time included the presence of PROM of more than 24 hours' duration, maternal fever $>38^{\circ} \mathrm{C}$ in the preceding 72 hours before delivery, dexamethasone treatment, pregnancy induced hypertension, spontaneous labour, and vaginal delivery. Infants born by caesarean section were classified as having PROM of zero hours' duration. Perinatal factors were used as dependent variables against BALF cell counts in a multiple regression model. In a separate group of six premature infants, four boys and two girls, BALF was performed on the first day of life, and inflammatory cells were probed for the $\mathrm{Y}$ chromosome.

\section{BRONCHOALVEOLAR LAVAGE}

Bronchoalveolar lavage was performed during routine endotracheal nursing care of the newborn infant performed on the neonatal unit, Hammersmith Hospital. Lavage was only performed when endotracheal suction was clinically indicated and no procedures additional to routine clinical care were required for this study. Parental consent was always obtained for this modified nursing procedure. Two separate aliquots of $1 \mathrm{ml} / \mathrm{kg}$ normal saline were instilled into the lung via a 5 French suction catheter $(<1.5 \mathrm{~mm}$ diameter with an end hole) sited in the right main bronchus. BALF was immediately aspirated 
after each instilled aliquot. Pooled BALF was filtered through a single layer of muslin gauze and the total number of cells in the BALF sample determined by haemocytometer (BALF cells $\times 10^{4}$ ). Cell viability was assessed by trypan blue exclusion and cytocentrifuge preparations (Cytospin 2, Shandon Products Ltd) stained with Diff Quick (Merz and Dade AG), or probed for the $Y$ chromosome using in situ hybridisation. Differential counts (\%) were calculated from 300 cells and BALF cultured for aerobic and anaerobic bacteria. The culture methods could not isolate Ureaplasma urealyticum or Mycoplasma hominis.

\section{Y CHROMOSOME IN SITU HYBRIDISATION}

BALF cells were probed using a method adapted from Simmons et al. ${ }^{4}$ Cytocentrifuge preparations were dried for 30 minutes and fixed in $10 \%$ formalin in phosphate buffered saline (PBS) for 10 minutes. Cells were permeabilised in $0.5 \%$ Triton $-\mathrm{X} 100$ in PBS for 10 minutes, then fixed in $10 \%$ formalin in PBS for five minutes, and treated with $0.25 \mu \mathrm{g} / \mathrm{ml}$ proteinase $\mathrm{K}$ in $20 \mathrm{mM}$ Tris and $2 \mathrm{mM}$ calcium chloride (pH 7.5) for 15 minutes at $37^{\circ} \mathrm{C}$ (all reagents, except where specified, from Sigma Chemical Co). A sample of $30 \mathrm{ng}$ of the biotinylated $\mathrm{Y}$ probe (pHY 2.1 from Amersham International; biotinylation kit from Gibco BRL) was desiccated and dissolved in $15 \mu$ l of hybridisation buffer ( $2 \times$ SSC, $50 \%$ formamide, $10 \%$ dextran sulphate, $0.5 \mathrm{mg} / \mathrm{ml}$ salmon sperm DNA) and hybridised overnight at $42^{\circ} \mathrm{C}$ after denaturing at $85^{\circ} \mathrm{C}$ for 10 minutes. The slides were rinsed in $2 \times S S C$, washed in $0.1 \times$ SSC for 40 minutes, and rewashed in $2 \times$ SSC. After blocking with $3 \%$ bovine serum albumin, the probe was detected by a mouse antibiotin antibody primary layer and a peroxidase conjugated rabbit antimouse antibody secondary layer (Dako Ltd). Both were applied at $1 / 20$ dilution in PBS for 30 minutes at room temperature. The signal was developed with $0.6 \mathrm{mg} / \mathrm{ml}$ diaminobenzidine and $0.02 \%$ hydrogen peroxide in PBS for five minutes. Slides were counterstained in $10 \%$ Leishman stain and mounted. Positivity, shown as an intracellular brown stain was assessed on 100 cells. Male adult $(n=4)$ blood mononuclear cells provided positive controls. Negative controls were BALF cells from the two infant girls.

Table 1 Total mean (SEM) BALF cell counts $\left(\log _{10} \times 10^{4}\right)$ in 74 infants of less than 32 weeks' gestation obtained before 24 hours of age, in relation to a series of perinatal factors

\begin{tabular}{|c|c|c|c|}
\hline \multirow[b]{2}{*}{ Perinatal factor } & \multicolumn{3}{|c|}{ BALF cell count } \\
\hline & Present/No & Absent/No & $p$ Value \\
\hline $\begin{array}{l}\text { PROM }>24 \text { hours } \\
\text { Spontaneous labour } \\
\text { Maternal fevert } \\
\text { Vaginal delivery } \\
\text { Maternal dexamethasone } \\
\text { Maternal hypertension } \\
\text { Gestation }>28 \text { weeks }\end{array}$ & $\begin{array}{l}1 \cdot 7(0 \cdot 12) / 27 \\
1 \cdot 3(0 \cdot 11) / 45 \\
1 \cdot 5(0 \cdot 17) / 16 \\
1 \cdot 3(0 \cdot 12) / 40 \\
1 \cdot 3(0 \cdot 14) / 37 \\
0 \cdot 8(0 \cdot 16) / 15 \\
1 \cdot 1(0 \cdot 13) / 36\end{array}$ & $\begin{array}{l}0 \cdot 7(0 \cdot 10) / 47 \\
0 \cdot 8(0 \cdot 15) / 29 \\
1 \cdot 0(0 \cdot 10) / 58 \\
0 \cdot 8(0 \cdot 13) / 34 \\
0 \cdot 9(0 \cdot 12) / 37 \\
1 \cdot 2(0 \cdot 11) / 59 \\
1 \cdot 0(0 \cdot 13) / 38\end{array}$ & $\begin{array}{l}<0.0001 \\
<0.01 \\
<0.01 \\
<0.05 \\
0.06 \\
0.08 \\
0.60\end{array}$ \\
\hline
\end{tabular}

*Significance by Student's $t$ test.

$\dagger>38^{\circ} \mathrm{C}$ during 72 hours before delivery.
ANALYSIS

Before analysis cell counts were $\log _{10}$ transformed. Perinatal risk factors for increased BALF cells were screened by univariate analysis using Student's $t$ test. Significant factors $(p<0.05)$ were then entered as background variables into a multiple regression analysis with BALF cell counts as the dependent variable.

\section{Results}

The volume of BALF returned averaged $1 \cdot 1$ $\mathrm{ml} / \mathrm{kg}, 56 \%$ of the volume of saline instilled. This proportion did not differ between those babies of mothers with PROM $<24$ hours and those with PROM $>24$ hours. No other risk factor was associated with any difference in the volume returned.

Of the seven perinatal factors recorded, PROM $>24$ hours, spontaneous labour, maternal fever $>38^{\circ} \mathrm{C}$, and vaginal delivery were associated with increased BALF cell numbers $(p<0.05$, table 1). Only PROM $>24$ hours was independently associated with increased BALF cells after multiple regression $(\mathrm{p}<0.0001, \mathrm{n}=74$, fig 1 , table 2$)$. The results were identical whether total cell counts or cell concentrations in the BALF were analysed.

Where BALF cell counts were less than $10 \times 10^{4}$, cytocentrifuge preparations consisted of mainly cellular debris with very few neutrophils (fig 2A). Recognisable inflammation was consistently present when BALF cell counts were $>30 \times 10^{4}$ with more than $90 \%$ of cells in these preparations shown to be viable neutrophils (fig 2B).

The two positive BALF cultures in the 74 infants were group D streptococcus (PROM $>24$ hours) and Citrobacter frendii (maternal fever). In one blood culture, $C$ frendii was isolated.

BALF cells from four culture negative newborn boys (two PROM >24 hours, two maternal fever) with pulmonary inflammation $\left(>50 \times 10^{4}\right.$ cells $)$ were probed. Inflammatory cell morphology was destroyed during the in situ hybridisation processing (fig $3 \mathrm{~A}, \mathrm{~B}$ ).

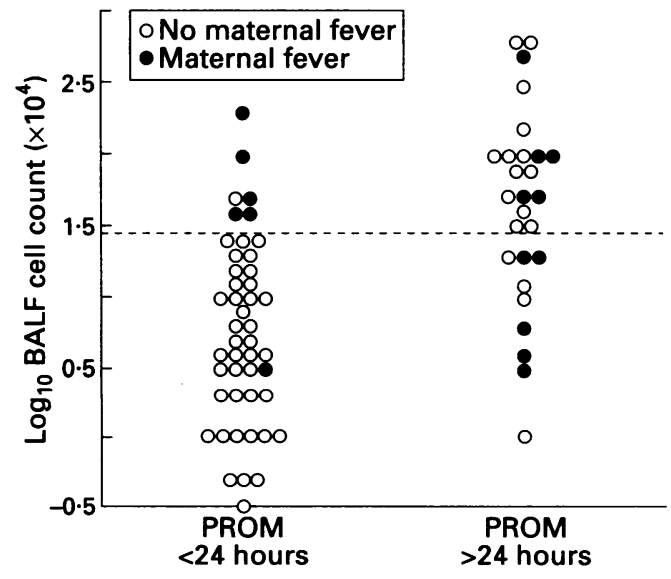

Figure $1 \log _{10}$ transformed $B A L F$ cell counts $\left(\times 10^{4}\right)$ in newborn premature infants with and without $P R O M$ of $>24$ hours' duration. Closed circles show infants born after maternal fever $\left(>38^{\circ} \mathrm{C}\right)$ during the 72 hours before delivery. Dotted line indicates $30 \times 10^{4}$ cells. 


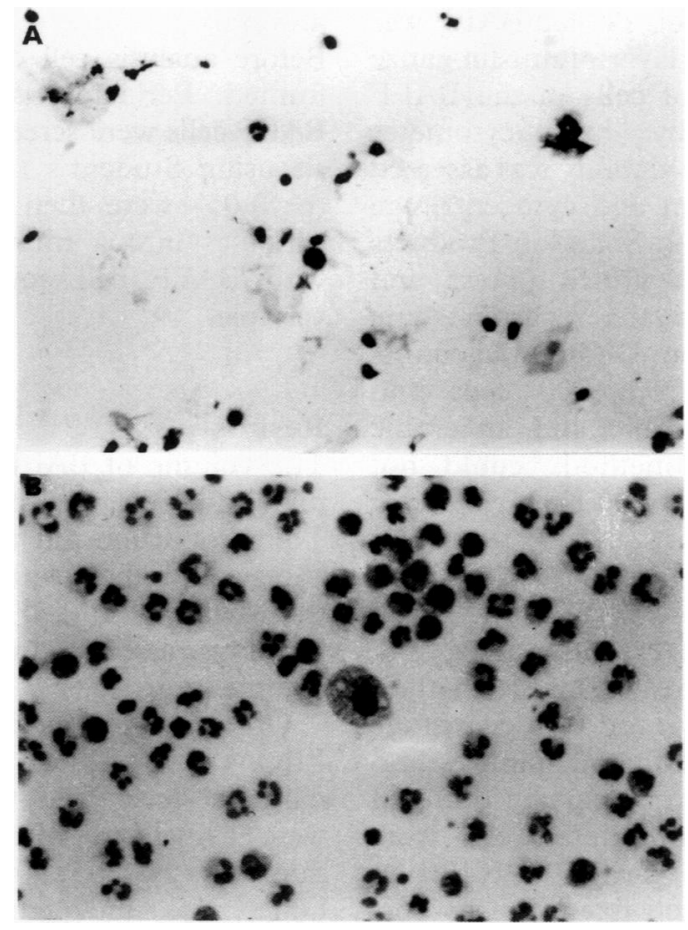

Figure 2 (A) BALF cells stained by Diff-Quick from an infant without $P R O M$ or maternal fever. Cellular debris present (magnification $\times 400$ ). (B) BALF cell preparation from an infant after PROM $>24$ hours. Significant neutrophilia is present with occasional mononuclear cells (magnification $\times 400$ ).

$Y$ positivity was $92,93,99$, and $100 \%$ respectively (fig $3 \mathrm{~A}$ ). Of the positive controls, 96-99\% of adult male mononuclear cells showed positivity $(n=4)$. Negative control BALF from newborn girls with pulmonary inflammation (two infants with PROM >24 hours), had $\mathrm{Y}$ positivity of $0-1 \cdot 5 \%$ (fig $3 \mathrm{~B}$ ). In

A
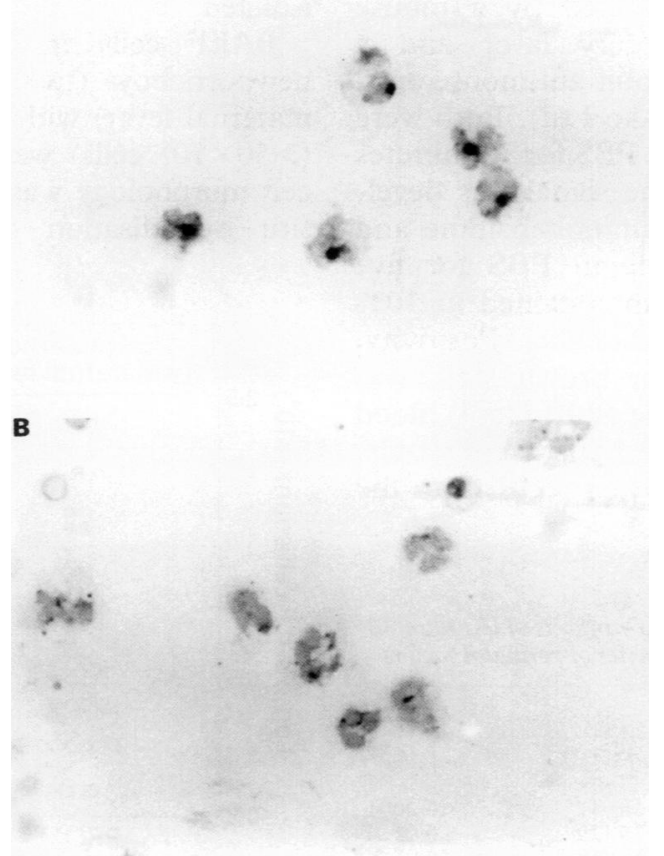

Figure 3 (A) Y chromosome in situ hybridisation of $B A L F$ cells from a male infant born after $P R O M>24$ hours. Dark spot indicates positivity (magnification

$\times 1000)$. (B) Y chromosome in situ hybridisation of female $B A L F$ afier $P R O M>24$ hours. No Y positivity; non-specific staining only (magnification $\times 1000$ ).
Table 2 Final multiple regression model with perinatal factors as background variables and $\log _{10} B A L F$ white cell count $\left(\times 10^{4}\right)$ as independent variable

\begin{tabular}{lcc}
\hline $\begin{array}{l}\text { Perinatal factors } \\
\text { (background variables) }\end{array}$ & $\begin{array}{l}\text { Regression coefficient } \\
(S D)\end{array}$ & p Value \\
\hline PROM >24 hours & $0.846(0 \cdot 169)$ & $<0.0001$ \\
Spontaneous labour & $0 \cdot 191(0.238)$ & 0.43 \\
Maternal fever & $0.213(0 \cdot 195)$ & 0.29 \\
Vaginal delivery & $-0.033(0.235)$ & 0.89
\end{tabular}

$\star>38^{\circ} \mathrm{C}$ during 72 hours before delivery.

$r^{2}=0.38, F=10 \cdot 62, p=0.0001$

Perinatal factor absent $=0$, present $=1$.

situ hybridisation with an $\mathrm{X}$ chromosome probe (method not shown) showed an absent double signal in all BALF cells from one boy after PROM and a 97\% double signal in cells from a girl after PROM.

\section{Discussion}

Using bronchoalveolar lavage we found that the only independent risk factor for increased numbers of airway leucocytes in intubated newborn infants $<32$ weeks' gestation was PROM for more than 24 hours. In a small separate group of infants, airway leucocytes were overwhelmingly of fetal origin and assuming maternal origin for amniotic fluid cells, ${ }^{3}$ no more than a tiny minority could have been inhaled directly from the amniotic fluid.

BALF cell counts were not corrected for differences in volume, as the proportion of saline that returned did not systematically vary between groups or risk factors. It is possible, using urea as a dilutional marker, to express BALF constituents in proportion to the epithelial lining fluid volume, ${ }^{5}$ but for cell counts this is not usual practice. ${ }^{6}$ Simply determining the cell concentration in BALF did not alter our conclusions.

BALF from the healthy adult lung contains a very low proportion of neutrophils $(<10 \%) .^{7}$ Similarly, histological analysis of newborn lungs has demonstrated no inflammatory cells within the alveoli and bronchi. ${ }^{8} \mathrm{~A}$ predominance of neutrophils in the neonatal airway is therefore not a feature of prematurity per se, but can be regarded as pathological. Fetal lung inflammation has been described as a result of congenital pulmonary infection. ${ }^{9}$ Moreover, in women with intact membranes, infection of the amniotic fluid is associated with amniotic fluid leucocytosis. ${ }^{10}$ Unfortunately membrane rupture makes it technically difficult to perform amniocentesis. As a result of this, amniotic fluid cytology and bacteriology have not been determined routinely after PROM. There is, however, indirect evidence that the concentration of amniotic fluid leucocytes increases with length of membrane rupture. Gastric aspirates obtained from infants in the first few hours of life contain predominantly swallowed maternal cells and reflect amniotic fluid cellularity. ${ }^{3}$ The number of leucocytes in the neonatal gastric aspirate rises as duration of membrane rupture increases. ${ }^{11}$ The airway leucocytosis demonstrated in the present study could therefore have been passively acquired from inhalation of amniotic fluid cells in utero or during 
delivery. However, our results using in situ hybridisation suggest that the airway cells were of fetal rather than maternal origin and represented a primary fetal response. The small number of boys studied should not have biased our results as the $\mathrm{Y}$ probe was both sensitive and specific and the infants were clinically representative of the group with significant airway leucocytosis.

The most obvious explanation for the independent effect of PROM $>24$ hours on airway cells at birth is fetal pulmonary infection acquired from the amniotic fluid. However, most of the BALF cultures in our study were negative. This dissociation between airway inflammation and proved bacterial infection may be explained in two ways. Firstly, it is likely that our cultures did not detect genuine bacterial infection either because of the prior use of antibiotics before or after delivery, or because the organisms would not grow on routine culture media. For instance, we could not detect $U$ urealyticum, an organism often isolated from the amniotic fluid during preterm labour. ${ }^{12}$ PROM $>24$ hours increases the incidence of ureaplasma isolation from neonatal tracheal aspirates. ${ }^{13}$ Whether this effect is due to ureaplasma entering the trachea during delivery or is a result of lung infection in utero is unknown.

A second possible mechanism for the initiation of fetal pulmonary inflammation is an effect of chemotactic mediators entering the fetal airway from the amniotic fluid. One such mediator, interleukin-8 (IL-8), is a potent neutrophil chemoattractant. ${ }^{14}$ High concentrations of IL-8 are associated with amniotic fluid leucocytosis. ${ }^{15}$ As both raised concentrations of IL-8 and amniotic fluid leucocytosis do occur without any infective agent, ${ }^{1015}$ cytokines in the fetal airway could result in pulmonary inflammation without any infection. IL-8 has not been measured in neonatal BALF but IL-6 is raised in lung epithelial lining fluid after PROM $>24$ hours. ${ }^{1}$ The role of these and other cytokines is speculative.

If maternal infection either directly or indirectly induces neonatal pulmonary inflammation, it is surprising that maternal fever had no independent effect on BALF leucocyte numbers. There was a trend for increased BALF cell counts with maternal fever where PROM was less than 24 hours (fig 1) and it is possible that this study had insufficient power to detect an independent effect. This could be due to the confounding clustering of perinatal factors into two broad groups: preterm labour with vaginal delivery after PROM or maternal fever, and caesarean section for pregnancy induced hypertension without PROM.

Irrespective of their aetiology, viable leucocytes in the airway are capable of releasing histiotoxic mediators. ${ }^{16}$ The influence of airway inflammation induced in utero on respiratory outcome has not been described, although isolation of $U$ urealyticum from tracheal aspirates of newborn infants is a risk factor for the development of chronic lung disease. ${ }^{13}$ Conversely, PROM $>16$ hours matures pulmonary surfactant and reduces the incidence of respiratory distress syndrome. ${ }^{17} 18$ As chronic lung disease may develop without early intubation, ${ }^{219}$ any future study into the effect of pulmonary inflammation in newborn infants should include data from non-intubated babies.

In conclusion, the presence of viable inflammatory cells in the airway of intubated preterm neonates is influenced by maternal rupture of membranes for more than 24 hours. Pulmonary inflammation at birth appears to be of fetal origin but a bacterial aetiology could not be demonstrated by our culture techniques. Although there appeared to be an association between inflammation in the neonatal lung and in the amniotic fluid, a direct relationship will only be demonstrated by the combination of amniocentesis and neonatal bronchoalveolar lavage.

We thank Dr John Savill for making available laboratory facilities. This work was supported by Action Research.

1 Grigg JM, Barber A, Silverman M. Increased levels of bronchoalveolar lavage fluid interleukin-6 in preterm ventilated infants after prolonged rupture of membranes. $A m$ Rev Respir Dis 1992; 145: 782-6.

2 Fujimura M, Takeuchi T, Kitajima H, Nakayama $M$. Chorioamniotitis and serum IgM in Wilson-Mikity syndrome. Arch Dis Child 1989; 64: 1379-83.

3 Vasan U, Lim DM, Greenstein RM, Raye JR. Origin of gastric aspirate polymorphononuclear leukocytes in infants born after prolonged rupture of membranes. f Pediatr 1977; 91: 69-73.

4 Simmons PI, Przepiorka D, Donnall Thomas E, TorokStorb B. Host origin of marrow stromal cells following Storb $B$. Host origin of marrow stromal cells following
allogenic bone marrow transplantation. Nature 1987; 328: 429-32.

5 Grigg J, Arnon S, Silverman M. Fractional processing of sequential bronchoalveolar lavage fluid from intubated babies. Eur Respir f 1992; 5: 727-32.

6 Walters EH, Gardiner PV. Bronchoalveolar lavage as a research tool. Thorax 1991; 46: 613-8.

7 The BAL Cooperative Group Steering Committee. Bronchoalveolar lavage constituents in healthy individuals, idiopathic pulmonary fibrosis and selected comparison

8 Robertson B. Pulmonary hyaline membranes of the newborn. Acta Pathologica et Microbiologica Scandinavica 1964; 62: $581-8$

9 Cassell GH, Davis RO, Waites KB, et al. Isolation of Mycoplasma hominis and Ureaplasma urealyticum from amniotic fluid at 16-20 weeks of gestation: potential effect on outcome of pregnancy. Sex Transm Dis 1983; 10: 294-302.

10 Romero R, Quintero R, Nores J, et al. Amniotic fluid white blood cell count: a rapid and simple test to diagnose microbial invasion of the amniotic cavity and predict preterm delivery. Am $\mathcal{f}$ Obstet Gynecol 1991; 165: preterm

11 Ramos A, Stern L. Relationship of premature rupture of the membranes to gastric fluid aspirate in the newborn. $A m \mathcal{f}$ Obstet Gymecol 1969; 105: 1247-51.

12 Romero R, Sirtori M, Oyarzun E, et al. Infection and labour V. Prevalence, microbiology and clinical significance of intraamniotic infection in women with preterm labour and intact membranes. Am $\mathcal{f}$ Obstet Gynecol 1989; 161: 817-24.

13 Cassell GH, Waites KB, Crouse DT, et al. Association of Ureaplasma urealyticum infection of the lower respiratory tract with chronic lung disease and death in very-lowtract with chronic lung disease and death
birth-weight infants. Lancet 1988; ii: 240-4.

14 Baggiolini M, Watz A, Kunkel SL. Neutrophil-activating peptide-1/interleukin-8, a novel cytokine that activates neutrophils. F Clin Invest 1989; 84: 1045-9.

15 Romero R, Ceska M, Avila C, Mazor M, Behnke E, Lindley I. Neutrophil attractant/activating peptide-1/interleukin-8 in term and preterm parturition. Am $\mathcal{f}$ Obstet Gynecol 1991; 165: 813-20.

16 Weiss SJ. Tissue destruction by neutrophils. $N$ Engl $₹$ Med 1989; 320: 365-76.

17 Bauer CR, Stern L, Colle E. Prolonged rupture of membranes associated with a decreased incidence of respiratory distress syndrome. Pediatrics 1974; 53: 7-14.

18 Perkins RP. The neonatal significance of selected perinatal events among infants of low birthweight II. The influence 7-12.

19 Edwards DK, Jacob J, Gluck L. The immature lung: radiographic appearance, course and complications. $A \mathscr{F R}$ 1980;
135: 659-66. 